\title{
Perspective
}

PERSPECTIVE Actualité en histoire de l'art

Comptes rendus | 2012

Gunnar Brands, Martin Maischberger éd., Lebensbilder : Klassische Archäologen und der Nationalsozialismus, (Menschen, Kulturen, Traditionen, 2), Rahden/Westf., Verlag Marie Leidorf, 2012

\section{Martin Bentz}

\section{(2) OpenEdition \\ Journals}

Édition électronique

URL : http://journals.openedition.org/perspective/2428

DOI : 10.4000/perspective.2428

ISSN : 2269-7721

Éditeur

Institut national d'histoire de l'art

Référence électronique

Martin Bentz, « Gunnar Brands, Martin Maischberger éd., Lebensbilder : Klassische Archäologen und der Nationalsozialismus, (Menschen, Kulturen, Traditionen, 2), Rahden/Westf., Verlag Marie Leidorf, 2012 »,

Perspective [En ligne], Comptes rendus, mis en ligne le 25 juillet 2013, consulté le 01 octobre 2020

URL : http://journals.openedition.org/perspective/2428; DOI : https://doi.org/10.4000/perspective. 2428

Ce document a été généré automatiquement le 1 octobre 2020. 
Gunnar Brands, Martin Maischberger éd., Lebensbilder : Klassische Archäologen und der Nationalsozialismus, (Menschen, Kulturen, Traditionen, 2), Rahden/ Westf., Verlag Marie Leidorf, 2012

Martin Bentz

\section{RÉFÉRENCE}

Gunnar Brands, Martin Maischberger éd., Lebensbilder : Klassische Archäologen und der Nationalsozialismus, (Menschen, Kulturen, Traditionen, 2), Rahden/Westf., Verlag Marie Leidorf, 2012. 
Contrairement à l'archéologie préhistorique, l'archéologie classique allemande ne s'est jusqu'ici que très imparfaitement occupée de son histoire sous le troisième Reich. On considérait généralement que la discipline ne s'était pas laissée embrigader, et qu'il ne s'y était trouvé occasionnellement que quelques nationaux-socialistes convaincus, qui

Menschen - Kulturen - Traditionen

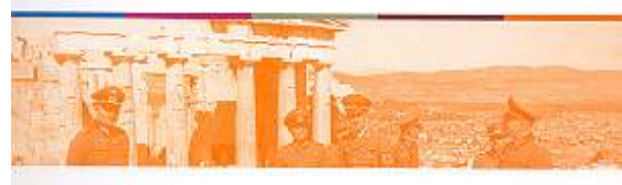

Qund 2, 1/Lebenstilder Klassis:he Anch Jologen und der Nationalsozialismus avaient cependant su faire la distinction entre leurs convictions personnelles et leur activité scientifique. Le recueil qui présente les biographies d'archéologues classiques sous le national-socialisme -un deuxième volume est prévu- vise à combler cette lacune par une approche nuancée, fondée sur les faits. Le projet ne comporte pas une histoire systématique Forschungs $C$ luster 5 Geschiche des Eeutsdien Arentosgisenan instruts im 20 . Jitrinurdert de l'époque, il la raconte à travers des biographies qui présentent aussi bien des personnes persécutées par le régime, que des complices passifs et des acteurs politiques. À cela s'ajoutent, pour compléter le tableau, des contributions sur certains archéologues étrangers étroitement liés à l'archéologie allemande. Les contributions sont fondées sur des recherches bibliographiques, mais aussi sur des matériaux d'archives inédits et sur des enquêtes menées auprès de témoins directs. Elles fournissent un tableau souvent neuf et très nuancé des personnalités, des parcours professionnels, des contraintes et des désespoirs de ces hommes de science, mais aussi de l'influence exercée par les événements politiques sur le travail archéologique. 